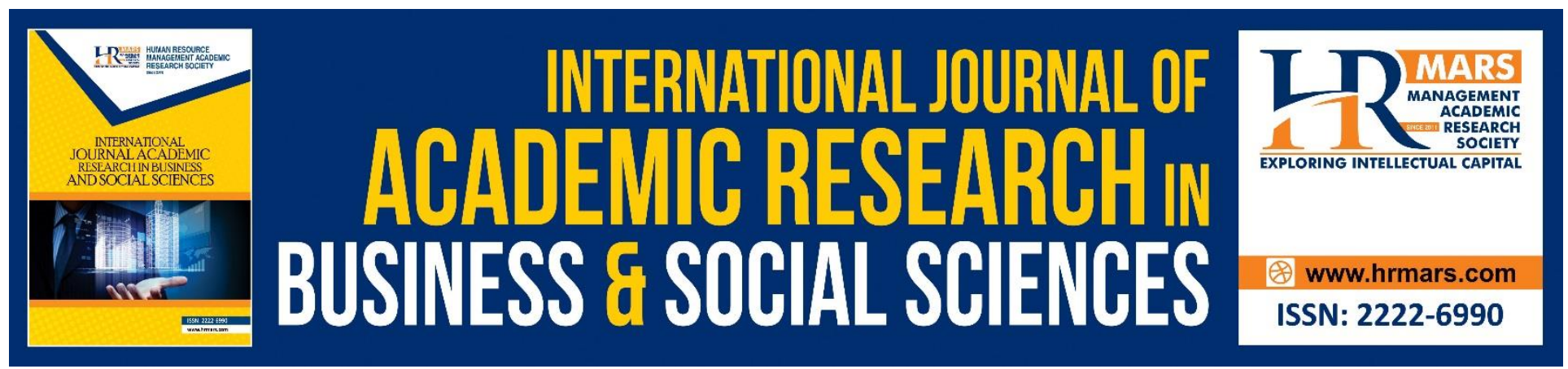

\title{
Political Trust Study: A Review
}

$\mathrm{Ng}$ Way Hoe, Zatul Himmah Adnan, Lee Yok Fee

To Link this Article: http://dx.doi.org/10.6007/IJARBSS/v11-i15/10632

DOI:10.6007/IJARBSS/v11-i15/10632

Received: 07 May 2021, Revised: 10 June 2021, Accepted: 29 June 2021

Published Online: 24 July 2021

In-Text Citation: (Hoe et al., 2021)

To Cite this Article: Hoe, N. W., Adnan, Z. H., \& Fee, L. Y. (2021). Political Trust Study: A Review. International Journal of Academic Research in Business and Social Sciences, 11(15), 15-27.

Copyright: (C) 2021 The Author(s)

Published by Human Resource Management Academic Research Society (www.hrmars.com)

This article is published under the Creative Commons Attribution (CC BY 4.0) license. Anyone may reproduce, distribute, translate and create derivative works of this article (for both commercial and non-commercial purposes), subject to full attribution to the original publication and authors. The full terms of this license may be seen

at: $\underline{\text { http://creativecommons.org/licences/by/4.0/legalcode }}$

Special Issue: Empowering Youth and Community Wellbeing for Sustainable Development, 2021, Pg. 15 - 27 http://hrmars.com/index.php/pages/detail/IJARBSS

Full Terms \& Conditions of access and use can be found at http://hrmars.com/index.php/pages/detail/publication-ethics 


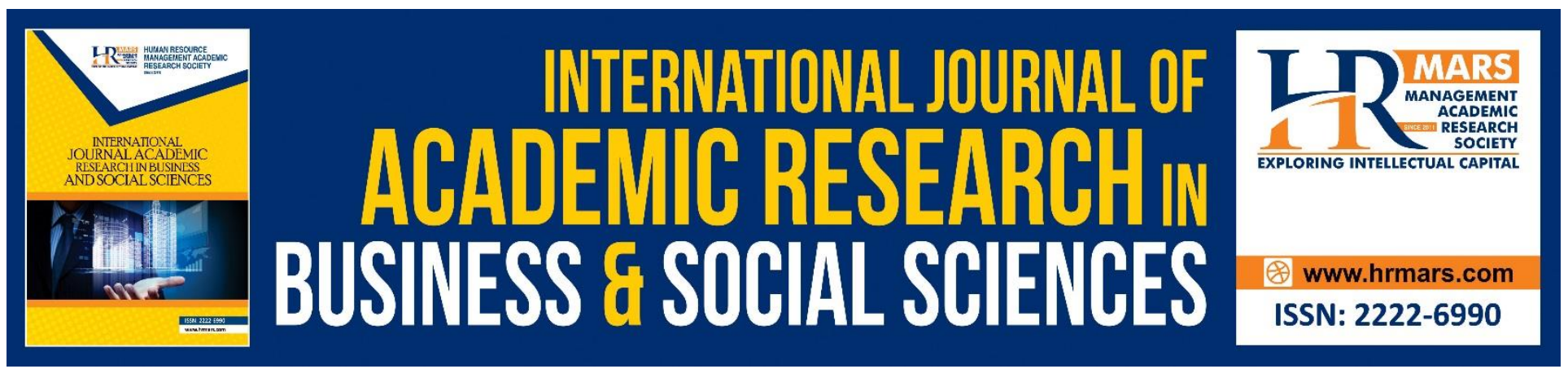

\title{
Political Trust Study: A Review
}

\author{
Ng Way Hoe, Zatul Himmah Adnan
}

Institute for Social Science Studies, Universiti Putra Malaysia, 43400, Serdang, Selangor, Malaysia

Faculty of Human Ecology, Universiti Putra Malaysia, 43400, Serdang, Selangor, Malaysia

Email: gavin2psy@yahoo.com, zatul@upm.edu.my

\section{Lee Yok Fee}

Institute for Social Science Studies, Universiti Putra Malaysia, 43400, Serdang, Selangor, Malaysia

Faculty of Human Ecology, Universiti Putra Malaysia, 43400, Serdang, Selangor, Malaysia

Email: leeyokfee@upm.edu.my

\begin{abstract}
Contemporary discourses on political trust study have always assumed that there is a direct relationship between trust in government; democratization and effectiveness in governance. However, the gradual decline of political trust has compelled scholars to revise this predominant notion. Reconceptualization of political trust to accommodate the on-going empirical findings has shown its conceptual resiliency. So, the question remains as to how political trust relates to democracy. This paper aims to suggest other developments that are currently overlooked by the traditional political trust studies but will eventually challenge the conventional understanding of the concept. By fostering more in-depth discussion, particular developments are specified; these include the implications of methodological sophistication, current interest in non-democracy or new democracy, and overgrown government institutions. The challenges and future outlook are also briefly discussed. The focus of this review confines to the relevant literature that provides crucial insights into the discussion of similar themes. The selection of published literature draws on databases or online resources in the past 20 years is guided by the application of key concepts such as measurement equivalent, post-communism, and so on. Overall, the resiliency of the political trust concept is found as viable as before, yet the new insights will enrich the multifaceted meaning of political trust concept. This paper offers not a conclusive answer to the challenges, but it set forth intelligibly the need to recognize some critical issues that are beyond the traditional trajectory. It straightens out the need for scholars to be more methodological informed, socio-culturally sensitive, and aware of the complexities of government institutions when researching in the future.
\end{abstract}

Keywords: Political, Trust, Political Trust Study, Democracy, Review. 


\section{Introduction}

Mishler and Rose (2001) once characteristically stated that "trust is critical to democracy." This assumption has been fundamental to the political trust study. Understandably, much of the literature on political trust then inferred a mutual correspondence of trust in government to democratic consolidation (Ceka, 2013; Marien \& Hooghe, 2011; Wang, 2013), as well as effectiveness in governance (Hetherington, 1998; Rudolph, 2009). However, the gradual decline of political trust among advanced democracies has posed a significant challenge to the dominant discourses (see Marozzi, 2015; Van de Walle, Van Roosbroek \& Bouckaert, 2008). An alternative interpretation is thus needed to explain the impact of widespread distrust on the health of democratic system. Bouckaert and Van de Walle (2001) contended, paradoxically, that the declining trust is not necessarily a crisis to democracy. Instead, it is rather an inevitable effect of socio-cultural change that resulted in a prevalent attitudinal shifting among the younger generation and subsequently led to the decline of political trust (Dalton, 2005). According to such view, the emerging critical citizens, accompanied by a compelling but healthy sense of scepticism towards political actors and institutions, are indeed instrumental to the functioning of democratic government.

The aforementioned is concerned about the consequences of political trust. It informs how the "trust" rating can have an impact on institutionalized democracy. The ongoing debate revolves around the theoretical nature of trust and the evolving character of trust subjects has led the scholars with differing opinions self-consciously dividing themselves into distinct schools of thought (Hooghe, 2017; see also Marien \& Hooghe, 2011; Tan \& Tambyah, 2011; Wang, 2005). One is either to play down the detrimental long-term effect of distrusting trend or boils down to a "crisis of democracy" that requires an immediate overhaul. Despite the conflicting interpretations of the (dis)trust phenomenon, the traditional political trust study remains adamant to defend its relevancy, especially to the legitimacy, viability, and vitality of democratic institutions. The concept of political trust remains as elusive as ever before, but its popularity survives the challenge for the last few decades (Citrin \& Stoker, 2018).

Against this framework, the present paper aims to postulate other forms of complexities beyond the traditional trajectory. Although these underlying issues are not necessarily exclusive to the conventional political trust study, it somehow intrinsically relates to the pre-existing problem concerning the theoretical underpinning of the trust notion. This review focuses on the relevant literature with similar themes that offer crucial insight on the subject matter, with each presents a different set of issues. This paper confines to only three predominant themes in the political trust study: A) the implication of methodological sophistication, B) the authoritarian regimes and new democracies, and C) the complex network of multilevel government institutions.

\section{The Implication of a Methodological Sophistication}

The availability of comparative surveys such as the European Social Survey, Asian Barometer Survey (ABS), and World Value Survey (WVS) has greatly stimulated the growing demand for cross-national research in political trust study. The comparative datasets are now readily obtainable. It enables the focus of trust study to break through the boundary of single nation analysis (Hooghe \& Marien, 2013; Marozzi, 2015; Wang, 2013). However, the success of comparative research is not without its challenge, as Schneider (2017) pointed out that the question always lies with the doubt on the comparability of various measurement models used in these studies. Any effort to compare the different measures of political trust in different countries will immediately confront the 
measurement equivalence issue. Measurement error and concept-measurement inconsistency are among the common problems the researchers constantly encounter in the cross-national measures of political trust, by and large, because of ambiguous understanding of its concept meaning (Bauer \& Freitag, 2017; Schneider, 2017). As such, there should be a renewed effort to reformulate how the conceptual idea of political trust is being translated into the concept measurement. Failure in resolving or, to the minimum, indemnifying such confounding effect will eventually render the comparative measures erroneous and invalid; and subsequently undermines its credibility and usefulness.

Technically, the challenges to the measurement reliability and the cross-national equivalence are not as straightforward as it first appears. It cannot be completely understood apart from the precursory problems underneath the nature of political trust measures itself. Syed (2016), contended that the primary independent problems for measurement parameters in political trust study have to do with the complexity of the subject matter at hand. He then identified several problems observed in the previous empirical studies that employed a simplistic way of measuring political trust by which they often: a) overlook the multidimensionality of the concept of trust; b) overestimate the respondents' understanding of such a complex concept; c) fail to appreciate the common ambivalent attitudes of the respondents; and d) heavily relying on the generalized single-item measure. "Measurement requires a clear conception of trust" (Bauer \& Freitag, 2017, p. 2), and hence without proper conceptualization, the effort for measurement standardization will eventually call into question.

Unlike the conventional treatment of political trust literature, the concept of trust is versatile and multidimensional. Likewise, what is equally important is to devise a robust and vibrant formulation for trust measurement. Although Johnson (1998) observed that there is still an absence of methodological consensus among practitioners, but the measurement problems have since been, whether completely or partially, sorted out with the new methodological techniques. Accompanied by theoretical rigor, empirical research has made significant progress in recent years. The serious attempt to construct an effective method to establish meaningful 'equivalence' is made possible when the standardization process undergoes careful undertaking accordingly to the pertinent measurement and statistical models (see Hooghe \& Marien, 2013; Poznyak, Meuleman, Abts \& Bishop, 2014). One of the most sought-after methods is confirmatory factor analysis (Parker, Parker, \& Towner, 2014), with which the comparison of latent constructs can be administered across populations (Turper \& Aarts, 2017). Confirmatory factor analysis is goodness-of-fit measures in which usually comprise other complementary measurements such as configure invariance, metric invariance, and scalar invariance measurement. Other than that, composite indicators are also popularly used for designing indexes in trust study, provided the individual indicators of the concept or phenomenon measured are arranged within the variable-specific theoretical framework (see Marozzi, 2015).

Despite its widespread use in cross-national analysis, confirmatory factor analysis and composite indicators have certain drawbacks. Turper and Aarts (2017) reminded the researchers to exercise some degree of caution. For instance, the assumption that each indicator has an equal contribution to the underlying latent construct in the composite score model should go through a careful calibration process in accordance with the appropriate weight applies to each of them so that it can produce a more robust finding. In other words, factor analysis is subject to the potential limit by multilevel invariance tests. Another suggestion for the scholars is to focus on a particular subset 
of countries that share more contextual similarities to reduce the risk of invariance error (see Tan \& Tambyah, 2011; Yap, 2019). Besides, Ariely and Davidov (2011) also called for deeper methodological reflection, not only on the evaluation strategies for various statistical models but also for better construction of measurement scales itself. In short, the venture into methodological experimentation has always been illuminating and rewarding, different technical suggestions can be used to promote improvements. However, the political trust researchers should be informed that, as the methodological sophistication continues to flourish, the theorizing process will also be shaped by it. In future studies, our understanding of political trust will inevitably continue to be reviewed and developed.

\section{The Authoritarian Regimes and New Democracies}

The study of political trust is usually conducted in a democratic setting or based on democratic assumptions. However, the current growing popularity of comparative research to include the countries which are not fully democratic in character and outlook poses another challenge to contemporary practitioners. Overall, two main questions deserve further examination. According to Rivetti and Cavatorta (2017), the first question deals with the reinterpretation of the long-held assumption of 'implied normativity of the concept' of political trust. The second question is the function of political trust in the non-democratic regimes. The logic that underlies these questions is to address the importance of a versatile understanding of political trust in a functioning nondemocratic regime and its relation to the issue of legitimacy.

Unlike the post-materialist cultures, where the concept of a political trust carries a strong democratic connotation, the non-democratic societies blur the value-based understanding and mostly reduce it to certain observable government performance indicators such as economic development. For instance, case studies in China by Wang (2005, 2005b) and comparative analysis in East Asia by Ma and Yang (2014) suggested the socio-economic performance as the major deciding factor to public confidence in government, with other potential mediating variables like the impact of modernization and the increased demand for political reform. When Yang and Tang (2010) explored in-depth the viability of over-reliance on economic performance by the Chinese government, the result showed ironically that the inevitable effect of economic prosperity essentially goes against the authoritarian regime's political mobilization effort to contain the emergence of 'critical citizens', by which the repercussion of modernization (namely political freedom and individual liberty) incubates at the peak of economic growth.

Besides, the effect of traditional values on political trust measures is another concerning issue. In authoritarian societies, trust is collectivistic and hierarchical (Shi, 2001). If this is taken prima facie, the understanding of trust has no difference from fidelity or patriotism. Although Wang (2005) demonstrated that the level of political trust among Chinese citizens is negatively associated with traditional values, the conclusion is somewhat premature if the likelihood of an impact of the hard approach (e.g., institutionalized intimidation) and the soft approach (e.g., implicit indoctrination and social pressure) is also taken into consideration. Probably, it deserves careful treatment in future studies. It is crucial to avoid the simplistic formulation that the inculcation of traditional values is understood independently of the overall political environment. Wang (2016) put a convincing case to prove that, among the Chinese students who had studied in Taiwan, about $50 \%$ of them experienced decreased political trust in the Chinese government. Exposure to liberal values gives rise 
to critical citizenship once again disputes the viability of a positive correlation between political trust and institutional legitimacy.

Several studies focusing on countries that have just adopted democracy after the new wave of democratization consistently exhibited the low trust phenomenon at the early stage of democratic transition (see Ceka, 2013; Gribovskaya, 2000). The new political system is accompanied by the introduction of social-political reform that is foreign to the people, has been significantly detrimental to the trust built in authoritarian regimes. However, once the democratization is consolidated, the uncertainty reduces, and the trust level would be gradually stabilized at a later stage (Letki, 2017). Despite that, it is still too early to conclude what else separates the democratic from the nondemocratic regimes concerning political trust. Other things being equal, as long as the assumption that political trust continues to be deemed vital to democracy, regardless of its complexity, a political institution is responsible to earn trust from the public by critically executing the policies which effectively reflect its conduct and performance.

\section{The Complex Network of Multilevel Government Institutions}

The effects of growing intricacy and interconnectivity between different government agencies, ranging from the local council to supranational commission, in which deal with a variety of policies that significantly implicates nearly all aspects of our daily lives, has largely overlooked in political trust study (Muñoz, 2017). The network of government institutions has become more and more complex; it evolving, more power centric, more bureaucratic in structure, and more elaborate in policing. Besides domestic responsibility, the national government also overlaps itself with the international realm. This multifaceted and multi-layered appearance has rendered the object of political trust somewhat elusive and ill-defined at times.

Van de Walle, Van Roosbroek, and Bouckaert (2008) explained that bureaucratization in a public sector is an expected outcome of the modernization process. Facing the increasing demand for public scrutiny, citizen participation acts as the impetus to the regular check-and-balance mechanism, inevitably encourages stringent formal regulation to promote more accountability in the modern-day government (Hilmer, 2010). Practically, the integrated public system also improves the policy coherence in governance with more resources and expertise to be garnered to address the issues that are far more complicated than we had in the past. For instance, the Total Defence Policy (HANRUH, the acronym for Pertahanan Menyeluruh) was proposed by the Ministry of Defence Malaysia in which the involvement and cooperation from all layers of society are appreciated in order to safeguard national security (National Defence Policy, 2010; MINDEF, 2020), is especially instrumental in wrestling with the growing unconventional threats such as cross-national terrorism and the sudden surge of Rohingya refugees seeking asylum in Malaysia. Internationally, the expansive globalization process also leads to the emergence of supranational organizations, as such the individual nation-states are compelled to organize themselves to regulate and oversee the businesses of these transnational entities. The list on the groupings of nation-to-nation multilateral relation now getting longer, the Asia-Pacific Economic Cooperation (APEC), the Association of Southeast Asian Nations (ASEAN), the European Union (EU), and the Group of Seven (G7), are perhaps the most wellknown amongst the others.

Having said that, our intention is not to dilute the force of the concept of government. Just the opposite, it is meant to enrich it. In political trust study, the idea of government is highly differentiated, but yet generalized in one way or another (Bouckaert \& Van de Walle, 2001). The 
(dis)trust in one level of the government is relative to the other level and vice versa. Theoretically speaking, local government tends to enjoy more trust than a higher-level government body that is commonly perceived as far more distant and centralized by the citizens (Muñoz, 2017; Bouckaert \& Van de Walle, 2001). Two factors require special attention. Firstly, the proximity and perceived high responsiveness in the lower-level institutions have often been attributed to higher performance satisfaction. In a responsiveness-performance framework, higher trust is inferred to the perceived outcome of government performance (Torcal, 2014; Vilhelmsdóttir \& Kristinsson, 2018). Therefore, it is believed that the local government with apportioned policy accountability is usually able to deliver swiftly, and subsequently receive a higher approval rate. However, political partisanship is also equally important. Political identification could significantly influence people's trust in government, particularly the local community in which the strong ties with the political parties, system, and bureaucracy are much highly appreciated (Miller \& Listhaug, 1990; Hooghe \& Kern, 2013). This fact becomes revealing if we examine the unique political structure in Belgian regional government where the political communities are mainly divided themselves into very stiff linguisticcultural demarcation (Hooghe, Marien \& Pauwels, 2011). In such circumstances, the trust in the federal government is at stake, vis-à-vis with the more trusted local government. At first glance, the tension that exists between local and federal government is definitive, but the full picture is yet to uncover unless the comparative evaluation extends to the international domain.

The public perception of the domestic performance of the local government is extensively subject to the performance of other counterpart countries. International comparison exists between the member states within the transnational alliance with a certain collaborative arrangement. The comparative dataset in the EU, such as Eurobarometer, enables us to identify the correlation between trust in a national government and the Union itself (see Harteveld, Van der Meer \& Vries, 2013). Let us look at how the perception of corruption implicates political trust in the nationalsupranational government. As argued by Tanzi (1998), the global economic transformation and international trading have necessitated a more vigilant attitude towards the issue of corruption; Transparency International (TI) is an exemplary inspiration for such effort. In EU countries where the public perception of corruption is relatively high, the pattern of political trust is comparatively low in the national rating and predictably high towards the EU (Torcal, 2014). A similar pattern is consistently found across European countries (Muñoz, 2017). However, the comparative analysis in the political trust study will only be meaningful if the public attitudes are taken into consideration the performance-specific governance (e.g., transparency, efficiency, or respect for liberty) for national-supranational institutions.

Trust in different levels of government is mutually involved and homologous in some sense ${ }^{1}$. It depends somewhat on the choice of an individual on what level of institutions is seen fit to be the basis for comparison. The government structure is usually hierarchically arranged, so the comparison can be either top-down or bottom-up or both concurrently. In future studies, the contention lie not only on the objects of trust (i.e., traditionally the categorization of what constitutes a government structure) but the nature of its interaction (i.e. how the character of each government institution relates to one another) demands further discussion.

\section{Challenges Ahead and Future Outlook}

In post-modern society, scholars must confront progression, innovation, and cultural pluralism. As the demand for democratization grows stronger and faster, the future political trust study just cannot 
afford to ignore the imminent trend, which will eventually define the new trajectory of scholarship. In other words, an effort for reconstruction in political trust study should be espoused by the necessary implicit adaption, in response to the immediate change. The main thrust of this paper is to revisit the current state of affairs and is looking forward to future development.

Scholarly interest in political trust is ever-growing, so much so that it now becomes a pressing subject of study in the realm of representative democracy (Van der Meer \& Zmerli, 2017). The need for the study is highly significant due to widespread conviction that the health of democracy is built on the trust of the subjects (e.g., voters, citizens) upon the objects of trust (e.g., politicians, government agencies). Seemingly, the "crisis of democracy" is popularly termed whenever there is a high rating of disapproval on either the head of government or the institution in the national poll or public survey. Merkel (2014) argued, on the other hand, that the conventional belief is subject to a challenge if the concept of democracy is specified. His suggestion has unprecedentedly shifted the focus of the debate and paved the way for a more comprehensive analysis.

A trusting relationship signifies a degree of predictability, which largely due to the confidence of trust subject in trust objects to behave expectedly. Choi and Woo (2016) explained that political trust is all about expectation towards the government. The simple formulation is expressed as " $A$ trust B to do x" (Fisher, van Heerde \& Tucker, 2010). In a democracy, it is invariably characterized by this sort of performance-based expectation of citizenry that drives the incumbent government to act responsibly and responsively. However, political pluralism is also being championed in a democratic society. Individual liberty always goes hand in hand with the endorsement of diversity, which is fundamental to a mature democracy. When different voices, representing diverse interest groups, demand equal opportunity to be heard, inter-group conflict is likely to trigger hostility, infighting, and partisanship. The institutional homogeneity is often underappreciated, and sometimes the diversity does more harm than good. No wonder non-democratic regime such as China still able to enjoy a moderately high level of public trust (Wang, 2017), but most democracies fall to the all-time low (Levi \& Stoker, 2000). Unsurprisingly, a culturally diverse society can be easily trapped into clientelism, and constant factionalism, by relying on political patronage for the interest of each party (Ufen, 2020). For instance, the most recent political crisis in Malaysia during the coronavirus outbreak, popularly known as "Sheraton Move", has shocked the nation and international community alike. Ironically, Merdeka Centre (2020) reported that the majority of Malaysians approved of Prime Minister Tan Sri Muhyiddin Yassin's performance while it is public knowledge that the current administration was formed established through non-democratic means and has no manifesto whatsoever. By contrast, the former government of Pakatan Harapan, which was initially elected through a formal process, had received much lower approval ratings, and whose election promises were impressive but unfulfilled due to unrealistic ambitions, is in stark contrast to the incumbent government.

If the proposition "political trust is critical to democracy" continues to stay relevant, it must immediately be followed by the "how" question. In what sense, exactly, does the political trust relate to democracy? After all, the relationship between political trust and democracy remains a subtle one. According to Yamaoka (2010), political trust is double-edged, possibly constrain or inspire government performance, depending on the accountability mechanism. Similarly, Fisher, van Heerde and Tucker (2010) also pointed out that the trust judgment is multifaceted, different both in form and levels. Besides knowing the ideal types of trust for various political institutions, it is equally important to understand under what conditions that citizens will be able to trust the most. As indicated by Warren (2018), a trust relationship is formed when trust judgment meets the 
trustworthy responses of those who are trusted. The variations in conceptual meaning simply cannot afford operational simplification. Hence, there is a plain outlook when considered all things; the complex measure of political trust will continue to prevail. The contiguity of closely related concepts makes it even more difficult to reach a scholarly consensus on the study of political trust. The next prospect is to foresee more subfields within the political trust study to develop. These include but are not limited to areas ranging from individual to meso/macro-level (Hamm, Smidt \& Mayer, 2019; Newton, 2001) and from cross-sectional to longitudinal (Kestilä-Kekkonen \& Söderlund, 2016; Kim, 2017). The interdisciplinary attempt, too, will push the limits of traditional studies. Lastly, as long as the political actors perceived political trust as important, the study shall remain relevant. High trust in government certainly streamlines the possible drawbacks of the execution of "displeasing" public policy onto any community. It is most evident for the continued demand of the younger generation, with a pursuit of new political agenda and participation styles, challenging the institutional rigidity to introduce rigorous reforms. The trust study is certainly significant to reconstruct our understanding of political engagement of the youth community.

\section{Conclusion}

In contemporary political trust study, the debate on the possible impact of continual decline of political trust on the vitality of democracy in the advanced democratic countries will persist. Either optimistic or pessimistic, our evaluation of prevalent scepticism in contemporary society demands a critical reflection. At times, some call for an urgent trust recovery; whereas, others believe political trust always coexists with healthy scepticism (Van der Meer \& Zmerli, 2017). Although the question is not completely irrelevant, however, the obsession with such discussion has often ignored other emerging issues. This paper argues that there are three threads of new developments that go beyond the trajectory of traditional scholarship, deserving further examination in future studies. The first is about the implication of methodological sophistication on political trust study, an easily overlooked subject that most literature takes for granted. Secondly, it is about the challenge of trust study in non-democracy or new democracy. It further questions the presumed feasibility of a democratic understanding of the political trust concept. And lastly, the sizeable multilevel network of government institutions blurs the clear demarcation of trust objects, subsequently reinforcing the continuum-discrete dichotomy approaches to the study. Overall, none of the contentions in this paper offers any conclusive answer to the questions, but it sets forth the need to recognize some critical issues that require further discussion.

\section{Acknowledgment}

The appreciation of the multilevel government in any independent sovereign state should also take into consideration of the different forms of government. For instance, the one-party states or military states are homogeneous; the theoretical differentiation of multilevel institutions seems superficial at best. As such, any attempt to impose the plain local-federal polarity that implies a sense of autonomy or independence for separate government institutions is futile and misleading. 


\section{References}

Ariely, G., \& Davidov, E. (2011). Can we rate public support for democracy in a comparable way? Cross- national equivalence of democratic attitudes in the World Value Survey. Social Indicators Research, 104(2), 271-286.

Bauer, P. C., \& Freitag, M. (2017). Measuring trust. In E. M. Uslaner (Ed.). The Oxford handbook of social and political trust. Oxford University Press.

https://doi.org/10.1093/oxfordhb/97801902748 01.001.0001

Bouckaert, G., \& Van de Walle, S. (2001). Government performance and trust in government. [Paper presentation]. EGPA Annual Conference 2001, Vaasa, Finland. Instituut voor de Overheid - K.U. Leuven.

Ceka, B. (2013). The causes and consequences of political trust and satisfaction with democracy in Eastern Europe (Doctoral dissertation). ProQuest Dissertations and Theses database.

Choi, E., \& Woo, J. (2016). The origins of political trust in East Asian democracies: Psychological, cultural and institutional arguments. Japanese Journal of Political Science 17(3), 410-426.

Citrin, J., \& Stoker, L. (2018). Political Trust in a Cynical Age. Annual Review of Political Science, 21, 49-70.

Dalton, R. J. (2005). The social transformation of trust in government. International Review of Sociology, 15(1), 133-154.

Fisher, J., van Heerde, J., \& Tucker, A. (2010). Does one trust judgement fit all? Linking theory and empirics. The British Journal of Politics and International Relations, 12, 161-188.

Gribovskaya, A. (2000). Students' political trust, efficacy, tolerance and interest in politics and civil learning in Russia (Doctoral dissertation). ProQuest Dissertations and Theses database. (UMI No. 9976726).

Hamm, J. A., Smidt, C., \& Mayer, R. C. (2019). Understanding the psychological nature and mechanisms of political trust. PLoS ONE 14(5): e0215835. https://doi.org/10.1371/journal.

Harteveld, E., Van der Meer, T., \& Vries, C.E.D. (2013). In Europe we trust? Exploring three logics of trust in the European Union. European Union Politics, 14(4), 542-65.

Hetherington, M. J. (1998). The political relevance of political trust. The American Political Science Review, 92(4), 791-808.

Hilmer, J. D. (2010). The state of participatory democratic theory. New Political Science, 32(1), 43-63. DOI: $10.1080 / 07393140903492118$

Hooghe, M. (2017). Review of the book Handbook on Political Trust, by S. Zmerli \& T. van der Meer]. Journal of Trust Research. DOI:10.1080/21515581.2017.1364481

Hooghe, M., \& Kern, A. (2013). Party membership and closeness and the development of trust in political institution: An analysis of the European Social Survey. Party Politics, 21(6), 944-956. https://doi.org/10.1177/1354068813509519

Hooghe, M., \& Marien, S. (2013). A comparative analysis of the relation between political trust and forms of political participation in Europe. European Societies, 15(1), 131-152.

Hooghe, M., Marien, S., \& Pauwels, T. (2011). Where do distrusting voters turn if there is no viable exit or voice option? The impact of political trust on electoral behaviour in the Belgian Regional Elections of June 2009. Government and Opposition, 46(2), 245-273.

Johnson, T. P. (1998). Approaches to equivalence in cross-cultural and cross-national survey research In J. Harkness (Ed.), Cross-cultural survey equivalence (pp. 1-40). Zentrum für Umfragen, Methoden und Analysen, ZUMA. https://nbn-resolving.org/urn:nbn:de:0168-ssoar-49730-6 
INTERNATIONAL JOURNAL OF ACADEMIC RESEARCH IN BUSINESS AND SOCIAL SCIENCES

Vol. 11, No. 15, Empowering Youth and Community Wellbeing for Sustainable Development, 2021, E-ISSN: 2222-6990 @ 2020 HRMARS

Kestilä-Kekkonen, E., \& Söderlund, P. (2016). Political trust, individual-level characteristics and institutional performance: Evidence from Finland, 2004-13. Scandinavian Political Studies, $39(2), \quad 138-160$.

Kim, S. (2017). Governance Values and Public Trust in Government: An Exploratory Study of Indonesia, Malaysia, and Thailand. KDI School of Pub Policy \& Management Paper, 17-10. https://papers.ssrn.com/sol3/papers.cfm?abstract_id=3103507

Letki, N. (2017). Trust in newly democratic regimes. In E. M. Uslaner (Ed.), The Oxford handbook of social and political trust. Oxford University Press. http://dx.doi.org/10.1093/oxfordhb/97801 90274801.013 .28

Levi M., \& Stoker, L. (2000). Political trust and trustworthiness. Annual Review of Political Science, 3, 475-507.

Ma, D. Y., \& Yang, F. (2014). Authoritarian orientation and political trust in East Asian societies. East Asia, 31, 323-341. http://dx.doi.org/10.1007\%2Fs12140-014-9217-z

Marien, S., \& Hooghe, M. (2011). Does political trust matter? An empirical investigation into the relation between political trust and support for law compliance. European Journal of Political Research, 50, 267-291.

Marozzi, M. (2015). Measuring trust in European public institutions. Social Indicators Research, 123, 879-895.

Merdeka Center. (2020). Perceptions towards economy, leadership and current issues, 15 July - 10 August 2020 [survey report]. Retrieved from https://merdeka.org/v2/download/nationalpublic- opinion-survey-perception-towards-direction-leadership-current-issues-2/\#

Merkel, W. (2014). Is there a crisis of democracy? Democratic Theory, 1(2), 11-25. http://dx.doi.org/10. 3167/dt.2014.010202

Mishler, W., \& Rose, R. (2001). What are the origins of political trust? Testing institutional and cultural theories in Post-Communist Societies. Comparative Political Studies, 34, 30-62.

Miller, A. H., \& Listhaug, O. (1990). Political parties and confidence in government: A comparison of Norway, Sweden and the United States. British Journal of Political Science, 20(3), 357-386. https://doi.org/10.1017/S0007123400005883

Ministry of Defence. (2020). Defence White Paper: A secure, sovereign and prosperous Malaysia. http://www.mod.gov.my/images/mindef/article/kpp/Defence\%20White\%20Paper.pdf

Muñoz, J. (2017). Political trust and multilevel government. In S. Zmerli, \& van der Meer, T. W. G. (Eds.), Handbook on political trust (pp. 69-88). Edward Elgar Publishing.

National Defence Policy. (2010). Malaysia's National Defence Policy. https://www.pmo.gov.my/wpcontent/uploads/2019/07/National-Defence-Policy.pdf

Newton, K. (2001). Trust, social capital, civil society, and democracy. International Political Science Review, 22(2), 201-214.

Parker, S. L., Parker, G. R., \& Towner, T. L. (2014). Rethinking the meaning and measurement of political trust. In C. Eder, I. C. Mochmann, \& M. Quandt (Eds.), Political trust and disenchantment with politics: International perspectives (pp. 59-92). BRILL publisher.

Poznyak, D., Meuleman, B., Abts, K., \& Bishop, G. F. (2014). Trust in American government: Longitudinal measurement equivalence in the ANES, 1964-2008. Social Indicators Research, 118(2), 741-758.

Rudolph, T. J. (2009). Political trust, ideology, and public support for tax cuts. Public Opinion Quarterly, 73(1), 144-158. 
INTERNATIONAL JOURNAL OF ACADEMIC RESEARCH IN BUSINESS AND SOCIAL SCIENCES

Vol. 11, No. 15, Empowering Youth and Community Wellbeing for Sustainable Development, 2021, E-ISSN: 2222-6990 @ 2020 HRMARS

Rivetti, P., \& Cavatorta, F. (2017). Functions of political trust in authoritarian settings. In S. Zmerli, \& van der Meer, T. W. G. (Eds.), Handbook on political trust (pp. 53-68). Edward Elgar Publishing.

Schneider, I. (2017). Can we trust measures of political trust? Assessing measurement equivalence in diverse regime types. Social Indicators Research, 133(3), 963-984. https://doi.org/10.1007/s11205-016-1400-8

Seyd, B. (2016). How should we measure political trust? presented at 'Political Studies Association Annual Conference', Brighton, 21 $1^{\text {st }}-23^{\text {rd }}$ March, 2016. https://www.psa.ac.uk/sites/default/files/ conference/papers/2016/Paper.v2.pdf

Shi, T. J. (2001). Cultural values and political trust: A comparison of the People's Republic of China and Taiwan. Comparative Politics, 33(4), 401-419.

Tan, S. J., \& Tambyah, S. K. (2011). Generalized trust and trust in institutions in Confucian Asia. Social Indicators Research, 103, 357-377.

Torcal, M. (2014). The decline of political trust in Spain and Portugal: Economic performance or political responsiveness? American Behavioral Scientist, 58(12), 1542-1567.

Turper, S., \& Aarts, K. (2017). Political trust and sophistication: Taking measurement seriously. Social Indicators Research, 130, 415-434.

Ufen, A. (2020). Clientelist and programmatic factionalism within Malaysian political parties. Journal of Current Southeast Asian Affairs, 00(0), 1-23.

Van de Walle, S., Van Roosbroek, S., \& Bouckaert, G. (2008). Trust in the public sector: Is there any evidence for a long-term decline? International Review of Administrative Sciences, 74(1), 47-64.

Van der Meer, T., W., G., \& Zmerli, S. (2017). The deeply rooted concern with political trust. In S. Zmerli, \& van der Meer, T. W. G. (Eds.), Handbook on political trust (pp. 1-15). Edward Elgar Publishing.

Vilhelmsdóttir, S., \& Kristinsson, G. H. (2018). Political trust in Iceland: Performance or politics? Icelandic Review of Politics and Administration, 14(1), 211-234.

Wang, C. C. (2016). Political socialization and change in political trust among mainland Chinese students studying in Taiwan. Japanese Journal of Political Science, 17(4), 527-544.

Wang, C. H. (2013). Causes and consequences of political trust in East Asia (Doctoral dissertation). https://uh-ir.tdl.org/handle/10657/2723

Wang, X. Z. (2017). A literature review of China's public political trust. Journal of Studies in Social Sciences and Humanities, 3(2), 42-47.

Wang, Z. X. (2005). Before the emergence of critical citizens: Economic development and political trust in China. International Review of Sociology, 15(1), 147-163.

Wang, Z. X. (2005b). Political trust in China: Forms and causes. In L. White (Ed.), Legitimacy: Ambiguities of political success or failure in East and Southeast Asia (pp. 113-139). World Scientific Press.

Warren, M. (2018). Trust and democracy. In Uslaner, E.M (ed.) The Oxford handbook of social and political trust, (pp. 75-94). Oxford: Oxford University Press.

Yamaoka, R. (2010). The art of governance: Performance, legitimacy, and trust. Y. Hagiwara (Ed.), Democracy and governance for civil society (pp. 29-44). Fukosha Publishing.

Yang, Q., \& Tang, W. F. (2010). Exploring the Sources of Institutional Trust in China: Culture, Mobilization, or Performance? Asian Politics and Policy, 2(3), 415-436. https://doi.org/10.1111/j.1943-0787.2010.01201.x 
INTERNATIONAL JOURNAL OF ACADEMIC RESEARCH IN BUSINESS AND SOCIAL SCIENCES

Vol. 11, No. 15, Empowering Youth and Community Wellbeing for Sustainable Development, 2021, E-ISSN: 2222-6990 @ 2020 HRMARS

Yap, O. F. (2019). How political trust matters in emergent democracies: Evidence from East and Southeast Asia. Journal of Public Policy, 39(2), 295-328. 